\title{
Corticotropin-Releasing Factor, Urocortin 1, and Their Receptors in the Mouse Spinal Cord
}

\author{
ANIKO KOROSI, ${ }^{1,2}$ TAMÁS KOZICZ, ${ }^{1 *}$ JAKUB RICHTER, ${ }^{1}$ JAN G. VEENING, ${ }^{2,3}$ \\ BEREND OLIVIER, ${ }^{2,4}$ AND ERIC W. ROUBOS ${ }^{1}$ \\ ${ }^{1}$ Department of Cellular Animal Physiology, Radboud University Nijmegen, 6525 ED \\ Nijmegen, The Netherlands \\ ${ }^{2}$ Department of Psychopharmacology, Utrecht Institute of Pharmaceutical Sciences and \\ Rudolf Magnus Institute of Neuroscience, Utrecht University, 3584 CA Utrecht, The \\ Netherlands \\ ${ }^{3}$ Department of Anatomy and Embryology, Radboud University Nijmegen, $6500 \mathrm{HB}$ \\ Nijmegen, The Netherlands \\ ${ }^{4}$ Department of Psychiatry, Yale University School of Medicine, \\ New Haven, Connecticut 06520
}

\begin{abstract}
Corticotropin-releasing factor ( $\mathrm{CRF})$ and urocortin 1 (Ucn1) are involved in stress adaptation. CRF receptor 1 (CRF1) binds $\mathrm{CRF}$ and Ucn1 with similar high affinity, but CRF receptor 2 (CRF2) binds $\mathrm{Ucn} 1$ with higher affinity than $\mathrm{CRF}$. We tested the hypothesis that in the spinal cord CRF and Ucn1 control peripheral components of the stress response, by assessing the distribution of CRF- and Ucn1-containing fibers, CRF1 and CRF2 mRNAs, and $\mathrm{CRF}$ receptor protein $(\mathrm{CRFR})$ in the mouse spinal cord, by using immunofluorescence and in situ hybridization. CRF, Ucn1, and CRFR occurred throughout the spinal cord. CRF fibers predominated in laminae I, V-VII, and X of Rexed. Ucn1 fibers occurred mainly in laminae VII and X and occasionally in lamina IX. Both CRFR mRNAs occurred in all laminae except the superficial laminae of the dorsal horn, but they exhibited different distributions, CRF2 mRNA having a wider occurrence (laminae III-X) than CRF1 mRNA (laminae III-VIII). Double immunofluorescence indicated that CRF and Ucn1 fibers contacted CRFR-containing neurons, mainly in laminae VII and X. The strongest co-distribution of CRF1 and CRF2 mRNAs with CRF and Ucn1 fibers appeared in lamina VII. CRF2 mRNA predominated in lamina IX together with Ucn1, whereas CRF2 mRNA predominated in lamina X, where it had similar distributions with each ligand. In view of the lamina-specific and similar distributions of the two CRF receptor mRNAs with their ligands, we suggest that CRF1 and CRF2 are involved in peripheral stress adaptation processes, such as modulation of stress-induced analgesia and the mediation of visceral nociceptive information by CRF2. J. Comp. Neurol. 502:973-989, 2007. ๑ 2007 Wiley-Liss, Inc.
\end{abstract}

Indexing terms: nonradioactive in situ hybridization; corticotropin-releasing factor; urocortin 1; peripheral stress adaptation

Hypothalamic corticotropin-releasing factor (CRF; Vale et al., 1981) plays a critical role in activating the hypothalamo-pituitary-adrenal (HPA) stress axis. In addition, various stressors elicit rapid alterations in autonomic nervous system activity via CRF produced in various extrahypothalamic sites in the central nervous system including the spinal cord (Merchenthaler et al., 1983; Schipper et al., 1983; Swanson et al., 1983; Puder and Papka, 2001). Extrahypothalamic CRF may act as a neurotransmitter (Brown et al., 1982; Brown, 1986; De Souza, 1995; Koob and Heinrichs, 1999) and may control a wide variety of peripheral aspects of the stress response (Fisher, 1989; Koob and Heinrichs, 1999), such as cardio-

\footnotetext{
*Correspondence to: T. Kozicz, Department of Cellular Animal Physiology, Faculty of Science, Radboud University Nijmegen, Toernooiveld 1, 6525 ED Nijmegen, The Netherlands. E-mail: tkozicz2000@yahoo.com

Received 29 November, 2005; Revised 19 September 2006; 21 December

DOI 10.1002/cne.21347

Published online in Wiley InterScience (www.interscience.wiley.com).
} 2006 
vascular activity, gastric acid secretion, gastrointestinal motility (Brown, 1986; Brown et al., 1982; Owens and Nemeroff, 1991), stress-induced analgesia (Larivière and Melzack, 2000), and visceral pain perception (Song and Takemori, 1990; Nijsen et al., 2005). These responses appear to be mediated primarily by $\mathrm{CRF}$ produced in and acting on various brain centers such as the cerebral cortex, the limbic system, the medulla, and the pons (Owens and Nemeroff, 1991).

However, the inhibitory effects of intrathecal administration of CRF on gastric acid secretion (Bell and De Souza, 1988) and on perception of visceral pain in rat (Song and Takemori, 1990; Nijsen et al., 2005) suggest that the spinal cord is also an important site of CRF control of autonomic stress responses. This idea is supported by the immunocytochemical demonstration of CRF fibers throughout the rat spinal cord, in the various laminae of Rexed (Rexed, 1952), especially in the marginal zone (lamina I), deeper regions of the dorsal horn (laminae $\mathrm{V}-\mathrm{VII}$ ), and around the central canal (lamina X). Moreover, CRF-immunoreactive (ir) fibers occur in the intermediolateral column (IML) of the thoracic and lumbar parts of the spinal cord (Merchenthaler et al., 1983).

Another member of the CRF peptide family, urocortin 1 (Ucn1; Vaughan et al., 1995) is also assumed to play important roles in stress adaptation (Skelton et al., 2000; Gaszner et al., 2004; Kozicz et al., 2004; Korosi et al., 2005). Ucn 1 is mainly expressed in the Edinger-Westphal nucleus (Chung et al., 1987; Vaughan et al., 1995; Bittencourt et al., 1999; Skelton et al., 2000; Latchman, 2002; Oki and Sasano, 2004), and Ucn1 fibers project to the lateral septal nucleus, dorsal raphe nucleus, and spinal cord. The extensive ramifications of Ucn1 fibers in the spinal cord (Bittencourt et al., 1999) may play a role in controlling thermogenesis (Parkes et al., 2001; De Fanti and Martinez, 2002) and stress-induced immunosuppression (Okamoto et al., 1998), possibly via the sympathetic nervous system. In all rat spinal cord segments, Ucn1 fibers occur in the intermediate gray (lamina VII), the central gray (lamina X), and the IML. Furthermore, moderate numbers of Ucn1-ir fibers are present in lamina I and in the ventral horn, some of them being closely apposed to motoneurons (Bittencourt et al., 1999).

In the brain, CRF and Ucn1 bind two types of G proteincoupled membrane receptors, CRF receptor 1 (CRF1) and CRF receptor 2 (CRF2; Potter et al., 1994). CRF1 binds CRF and Ucn1 with similar high affinity (Vaughan et al., 1995; Chalmers et al., 1996), but CRF2 binds Ucn1 with about 40 times higher affinity than CRF1 (Lovenberg et al., 1995; Vaughan et al., 1995). CRF and Ucn1, as well as their receptors, have different distributions in the brain. This differential occurrence suggests that each neuropeptide plays its own role in orchestrating behavioral, neuroendocrine, and autonomic responses to stress, by acting in specific brain structures on either CRF1 or CRF2 (Turnbull and Rivier, 1997; Reul and Holsboer, 2002). In analogy, one would expect that in the spinal cord the same siteand receptor-specific actions of CRF and Ucn1 would be involved in controlling peripheral components of the stress response. However, evidence supporting this latter hypothesis is lacking, as information regarding the possible presence of CRF receptors (CRFRs) in the spinal cord is scarce. Receptor autoradiography in rat has shown strong CRF binding in the superficial layers of the dorsal horn (laminae I and II) and moderate CRF binding in the ventral horn of lumbar segments (Skofitsch et al., 1985; Bell and De Souza, 1988; De Souza, 1995). Furthermore, CRF2 mRNA has been demonstrated in the rat spinal cord by reverse transcriptase-polymerase chain reaction (RTPCR; Million et al., 2005). Spinal cord CRF receptors have been implicated in the mediation of colonic motor responses to centrally injected CRF and to stressful stimuli (Maillot et al., 2003) as well as the mediation of sensory transmission of visceral noxious stimuli (Larivière and Melzack, 2000).

Thus it appears that only in rat have CRF, Ucn1, and CRFR been demonstrated in the spinal cord, where CRF and CRF2 may be involved in regulation of peripheral stress responses. However, evidence for such a role is lacking for Ucn 1 and for our hypothesis that CRF and Ucn1 might act on different $\mathrm{CRF}$ receptors in different regions of the spinal cord. To provide such evidence, the present study mapped and assessed semiquantitatively 1) the distribution of CRF and Ucn 1 fibers by using immunohistochemistry; and 2) the distributions of CRF1 and CRF2 by using immunohistochemistry and in situ hybridization in the various Rexed laminae of the four parts of the spinal cord in the mouse. The functional significance of the results is discussed in relation to the presence of CRF and Ucn 1 fibers and their possible targets. The mouse was chosen for this study because of its increasing importance in experimental studies on the mechanisms of the stress response (e.g., Smith et al., 1998; Coste et al., 2000; Bale et al., 2002; Groenink et al., 2002; Imaki et al., 2003; Korosi et al., 2005) and because of our experience in demonstrating CRF1 and CRF2 mRNAs in the mouse brain at the cellular level by using nonradioactive in situ hybridization (Korosi et al., 2006).

\section{MATERIALS AND METHODS}

\section{Animals}

Three 12-week-old male C57BL/6J mice were housed in standard plastic cages in a temperature- and humiditycontrolled environment and maintained on a 12/12-hour light/dark cycle. They had free access to food and water. All procedures were approved by the ethical committee on animal experimentation of the Departments of Pharmacy, Biology, and Chemistry of Utrecht University, according to the Dutch law for animal experimentation and the Helsinki Declaration.

\section{Tissue processing}

Each mouse was deeply anesthetized by intraperitoneal injection with $0.1 \mathrm{ml} 6 \%$ sodium pentobarbital (Nembutal; Sanofi Santé, Maassluis, The Netherlands) and transcardially perfused with sterile saline (for 2 minutes) followed by freshly prepared $4 \%$ paraformaldehyde in RNAse-free $0.1 \mathrm{M}$ sodium phosphate buffer $(\mathrm{pH} 7.4 ; 100 \mathrm{ml} / \mathrm{mouse} ; 15$ minutes). After perfusion, spinal cords were dissected and postfixed in $4 \%$ paraformaldehyde for 16 hours at $4^{\circ} \mathrm{C}$ and stored in autoclaved $0.1 \mathrm{M}$ sodium phosphate-buffered saline (PBS) at $4^{\circ} \mathrm{C}$. Prior to cutting, tissues were transferred to $30 \%$ sucrose in $0.1 \mathrm{M}$ PBS for 16 hours at $20^{\circ} \mathrm{C}$ and frozen in dry ice. Each spinal cord was cut in $30-\mu \mathrm{m}-$ thick coronal sections at intervals of $210 \mu \mathrm{m}$; sections were stored in sterile antifreeze solution (0.05 M PBS, $30 \%$ ethylene glycol, $20 \%$ glycerol) at $-20^{\circ} \mathrm{C}$ until processing. 


\section{Probes}

The mouse CRF1 probe was generated from a $1.2-\mathrm{kb}$ cDNA encompassing the entire coding region of the receptor obtained by RT-PCR amplification from AtT-20 cells, by using primers based on the human brain R1 sequence, which displays $97 \%$ amino acid sequence identity with mouse (Van Pett et al., 2000; Korosi et al., 2006). CRF2 $\alpha$ probes encompass $0.9 \mathrm{~kb}$ of the coding sequence and $0.1 \mathrm{~kb}$ of the $5^{\prime}$ untranslated region of the mouse CRF2 $\beta$ (Van Pett et al., 2000; Korosi et al., 2006). Antisense and sense (control) RNA probes were synthesized by using CRF1 and CRF $2 \alpha$ cDNAs (kindly provided by Dr. W.W. Vale, San Diego, CA) and labeled with DIG-11-UTP by using a labeling kit from Roche Molecular Biochemicals (Basel, Switzerland).

\section{In situ hybridization}

In situ hybridization of CRF1 and CRF $2 \alpha$ mRNAs was carried out with the free-floating section method (Jessell; http://cpmcnet.columbia.edu/dept/neurobeh/jessell/

insitu.html), with minor modifications, as follows. In situ hybridization steps were carried out at $20^{\circ} \mathrm{C}$ unless stated otherwise. First, sections were fixed in $0.1 \mathrm{M}$ boraxbuffered $4 \%$ paraformaldehyde ( $\mathrm{pH} 9.5$ ), at $4{ }^{\circ} \mathrm{C}$ for 30 minutes. Then they were rinsed four times for 7 minutes with $0.1 \mathrm{M}$ PBS and preincubated in proteinase $\mathrm{K}$ medium (0.1 M Tris-HCl, 0.05 M EDTA, $0.1 \mathrm{mg}$ proteinase $\mathrm{K}$ ), for 10 minutes at $37^{\circ} \mathrm{C}$. After rinsing in autoclaved $\mathrm{MQ}$ water, acetylation was performed with $0.25 \%$ acetic acid anhydride in $0.1 \mathrm{M}$ tri-ethanolamine buffer ( $\mathrm{pH} 8.0$ ), for 10 minutes, followed by rinsing in two times concentrated $(2 \times)$ standard saline citrate buffer (SSC; pH 7.0), for 5 minutes. The hybridization mixture (50\% deionized formamide, 0.3 M NaCl, 0.001 M EDTA, Denhardt's solution, $10 \%$ dextran sulfate), together with $0.5 \mathrm{mg} / \mathrm{ml}$ tRNA and the mRNA-digoxigenin (DIG) probe (ca. $2.5 \mathrm{ng} / \mathrm{ml}$ ), was placed into a water bath for 5 minutes at $80^{\circ} \mathrm{C}$ and then on ice for another 5 minutes.

Sections were incubated in hybridization solution, for 16 hours at $60^{\circ} \mathrm{C}$, rinsed four times for 7 minutes with $4 \times$ $\mathrm{SSC}$, incubated for 30 minutes at $37^{\circ} \mathrm{C}$ in preheated RNAse medium (0.5 M NaCl, 0.01 M Tris-HCl, 0.001 M EDTA, $0.01 \mathrm{mg} / \mathrm{ml}$ RNAse A; pH 8.0) that had been added just before the start of incubation, and stringently washed with decreasing SSC concentrations $(2 \times, 1 \times, 0.5 \times$, and $0.1 \times)$, for 30 minutes at $58{ }^{\circ} \mathrm{C}$. The alkaline phosphatase (AP) method with nitroblue tetrazolium chloride/5-bromo4-chloro-3-indolyl phosphate toluidine salt (NBT/BCIP) as substrate was used to detect DIG label. Briefly, after rinsing four times for 5 minutes with buffer A (0.1 M Tris-HCl, $0.15 \mathrm{M} \mathrm{NaCl} ; \mathrm{pH} 7.5$ ), sections were preincubated in buffer A containing $0.5 \%$ blocking agent (Roche Molecular Biochemicals), for 1 hour, followed by 3 hours of incubation with sheep anti-DIG-AP (Roche Molecular Biochemicals; 1:5,000) in buffer A containing $0.5 \%$ blocking agent. Subsequently, sections were rinsed four times for 5 minutes in buffer A, followed by two 5 -minute rinses in buffer $\mathrm{B}(0.1$ M Tris-HCl, 0.15 M NaCl, 0.05 $\mathrm{M} \mathrm{MgCl}_{2}$; pH 9.5). After 16 hours of incubation in NBT/BCIP medium (10 ml buffer B, $2.4 \mathrm{mg}$ levamisole, $175 \mu \mathrm{l} \mathrm{NBT/BCIP}$ mixture; Roche Molecular Biochemicals) in a light-tight box, the reaction was stopped by rinsing twice for 5 minutes in buffer $\mathrm{C}(0.1 \mathrm{M}$ Tris-HCl, 0.01 M EDTA; pH 8.0). Then sections were mounted on gelatin-coated glasses, dried for 16 hours at $37^{\circ} \mathrm{C}$, rinsed in distilled water, dehydrated, cleared in xylene, and coverslipped with Entellan.

\section{Immunofluorescence}

For single and double immunohistochemistry, sections were washed three times at 20 minutes each in PBS and then incubated in $1 \%$ Triton X-100 solution for 30 minutes and in $2 \%$ normal donkey serum (Jackson ImmunoResearch Laboratories, West Grove PA) in PBS for 1 hour. Then, for single labeling for CRF, Ucn1, and CRFR, sections were incubated in, respectively, polyclonal (rabbit) anti-CRF (8Bo; 1:2,000; generous gift from Dr. F.J.H. Tilders, Free University, Amsterdam, The Netherlands), polyclonal (rabbit) anti-Ucn1 (1:15,000; PBL\#5779, generous gift from Dr. W.W. Vale), and polyclonal (goat) antiCRFR (1:800; sc-1757, Santa Cruz Biotechnology, Santa Cruz, CA). For double labeling of CRF fibers contacting CRFR-containing neurons, sections were treated with a mixture of (goat) anti-CRFR (1:800) and rabbit anti-CRF (1:200) for 16 hours at $20^{\circ} \mathrm{C}$. To identify Ucn 1 fibers contacting CRFR-containing neurons, sections were incubated in a mixture of (goat) anti-CRFR (1:100) and (rabbit) anti-Ucn1 $(1: 15,000)$ for 16 hours at $20^{\circ} \mathrm{C}$. After three 15-minute PBS washes, for single labeling, a secondary antiserum (Cy3-conjugated anti-goat IgG; 1:100 or Cy3conjugated anti-rabbit IgG; 1:100) was applied for 3 hours at $20^{\circ} \mathrm{C}$. For double labeling, sections were incubated for 3 hours at $20^{\circ} \mathrm{C}$ in a cocktail of, respectively Cy2-conjugated anti-goat IgG; (1:100) and Cy3-conjugated anti-rabbit IgG; (1:100); or Cy3-conjugated anti-goat IgG; (1:100) and Cy2conjugated anti-rabbit IgG; (1:100).

\section{Antiserum characterization}

The CRF antiserum (8Bo) was generated against whole rat $\mathrm{CRF}$ (amino acids $1-41$ ). The antiserum was characterized by immunospotting. The $\mathrm{r} / \mathrm{hCRF}$ antiserum showed an antibody-concentration-dependent staining, i.e., spots of CRF showed a concentration-dependent staining from $10^{-8}$ to $10^{-5} \mathrm{M} \mathrm{CRF}$, and staining of $10^{-6} \mathrm{M} \mathrm{CRF}$ was completely abolished by preincubation of the CRF antiserum with $10^{-6} \mathrm{M} \mathrm{CRF}$ (for 2 hours at $37^{\circ} \mathrm{C}$ ). No staining was observed with vasopression, oxytocin, or $\alpha$-melanocyte-stimulating hormone ( $\alpha \mathrm{MSH})$ spots (up to $10^{-3} \mathrm{M}$ ). For further details, see Mulders et al. (1995).

The Ucn1 antiserum was generated against whole rat Ucn1 (amino acids 1-40). The high specificity of the Ucn1 antiserum was controlled by preadsorption with the synthetic peptide $(0.1$ and $1.0 \mu \mathrm{g} / \mathrm{ml}$ diluted antiserum $)$ used to generate the antiserum. Preadsorption with $0.1 \mu \mathrm{g}$ synthetic peptide completely abolished immunoreactivity in the rat midbrain in all cases (for further details, see Bittencourt et al., 1999; Turnbull et al., 1999).

The polyclonal (goat) CRFR antiserum was generated in goat against a 20-amino acid peptide sequence (Santa Cruz Biotechnology). The CRFR (C-20, sc-1757) antibody reacts with both CRFR1 and CRFR2. The synthetic peptide antigen, comprising the C-terminus of CRFR (SIPTSPTRVSFHSIKQSTAL), corresponds to amino acids 425-444 of human CRF1 and is identical to amino acids 396-415 of mouse and rat CRFR. A search of GenBank databases revealed no known sequences (aside from CRF receptors of other species) with significant homology to this portion of the CRF receptors. Preadsorption of the primary antiserum with the blocking peptide consisting of the immunogenic epitope $(100 \mu \mathrm{g} / \mathrm{ml})$ completely abol- 

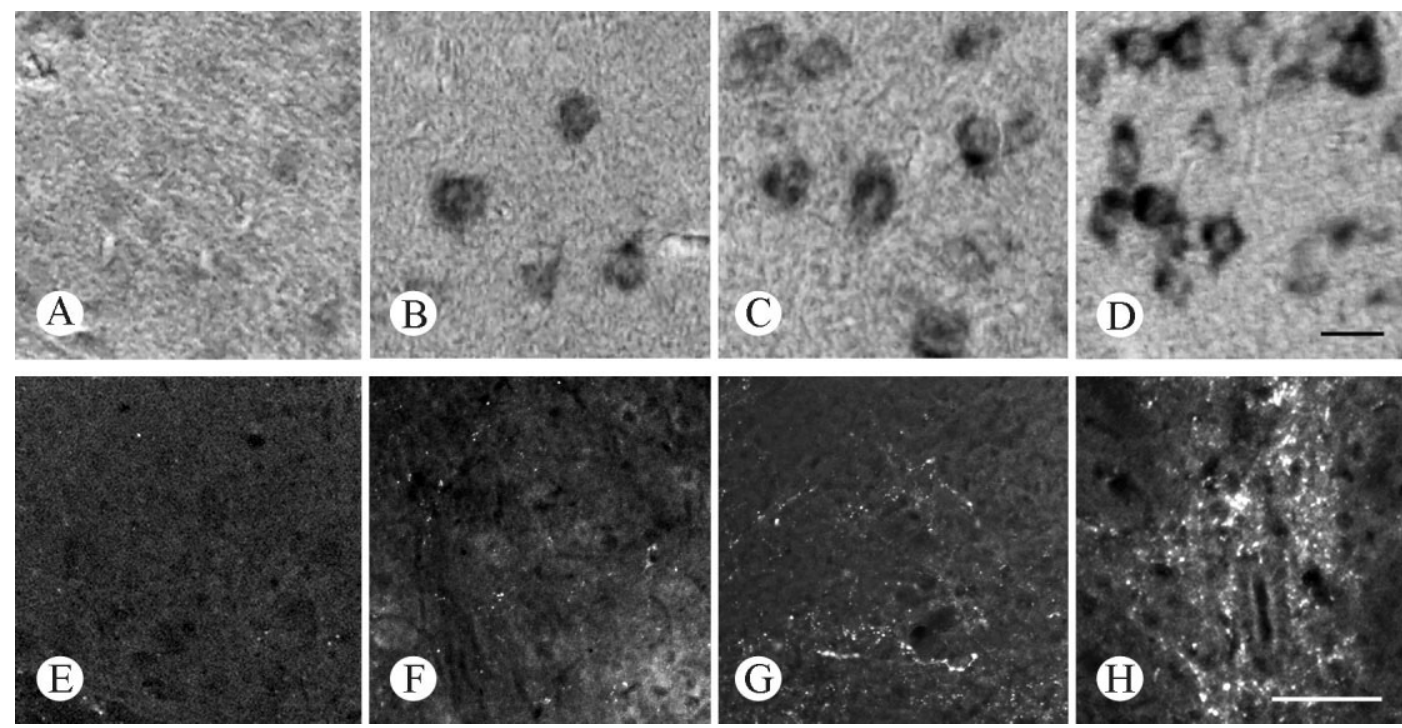

Fig. 1. Photomicrographs of representative coronal sections of the mouse spinal cord, demonstrating different labeling densities of (A-D) neuronal perikarya stained by in situ hybridization for CRF1 mRNA and (E-H) fibers immunostained for CRF. A,E: No labeling. B,F: Low labeling. C,G: Moderate labeling. $\mathrm{D}, \mathrm{H}$ : High-density labeling. Scale bar $=20 \mu \mathrm{m}$ in D (applies to A-D); $100 \mu \mathrm{m}$ in H (applies to E-H).

ished the CRF receptor band. (for further details, see Chen et al., 2000; Kimura et al., 2002; Sehringer et al., 2000).

In additional testing, when primary antisera against Ucn1, CRF, and CRFR were omitted or replaced by nonimmune goat or rabbit sera in concentrations of the respective primary sera, no immunoreactions were observed.

\section{Microscopic analysis}

Different parts of the spinal cord were identified according to Sidman et al. (1971); the laminae of Rexed were identified with reference to adjacent Nissl-stained sections, according to the description by Molander and Grant (1995) for the rat, which equally applies to that of the mouse (Li and Clark, 2001). The strengths of the immunoreactions of CRF, Ucn1, and CRFR, and the numbers of labeled neurons and strengths of the in situ hybridization signals of CRF1 and CRF2 mRNA in a given lamina and part of the spinal cord were assessed by direct microscopic analysis and translated into a semiquantitative scale, as follows: - , absent or very rare; + , low; ++ , moderate; or +++ , high (Fig. 1 and Table 1). This approach does not allow direct comparison of the amount of $\mathrm{CRF}$ versus Ucn1 or of CRF1 mRNA versus CRF2 mRNA, as the efficiencies of the immunostainings, as well as the hybridizations, are unknown and may differ from each other. However, it does provide detailed information on the relative distributions of CRF, Ucn1, CRFR, and CRF1 and CRF2 mRNAs in the four parts and in the various laminae of the spinal cord.

\section{Digital imaging of illustrations}

Confocal microscopy was carried out with a Leica TCSSP2-AOBS confocal laser scanning microscope attached to a Leica DM IRE2 inverted epifluorescence laser with brightfield, by using a 488-nm Ar laser and a 561-nm orange laser (Leica Microsystems, Mannheim, Germany).
All confocal microscopy was performed by using $20 \times$ dry and $63 \times$ oil immersion objectives. Confocal images were processed by using overlays of the two channels and the standard Leica software. Digital images of sections were taken at 1,200 × 1,600 dpi by using the software supplied with the Leica DC 500 digital camera. Images were imported into Adobe Photoshop 7.0, digitally adjusted if necessary for gray levels as well as sharpness, and assembled into plates at a resolution of $400 \mathrm{dpi}$.

\section{RESULTS \\ General remarks}

The distributions of CRF, Ucn1, and CRFR immunoreactivity and of CRFR mRNA hybridization signals were examined in coronal sections in the four parts (cervical, thoracic, lumbar, and sacral) of the spinal cord (Figs. 2-10). The three mice studied gave essentially the same results. CRF, Ucn1, and both CRFR mRNAs were seen throughout the whole length of the spinal cord, and their distributions appeared to be very similar in all parts. Representative illustrations are presented in Figures 2 and 5. The distributions in the 10 laminae of Rexed are described in detail below. For a summary, see Table 1.

\section{CRF fiber distribution}

In all parts of the spinal cord, the gray matter contained beaded CRF-ir fibers, which displayed irregularly spaced varicosities of variable size. Most of the fibers were distributed in the deeper regions of the dorsal horn, primarily in laminae I, II, V-VII, and X (Fig. 3A-E). In addition, strongly stained fibers occurred in the white matter immediately lateral to the marginal zone in the dorsal part of the lateral funiculus (reticular formation; Fig. 3A). These fibers ran between the white matter and the intermediolateral sympathetic column in lamina VII. In the dorsal 


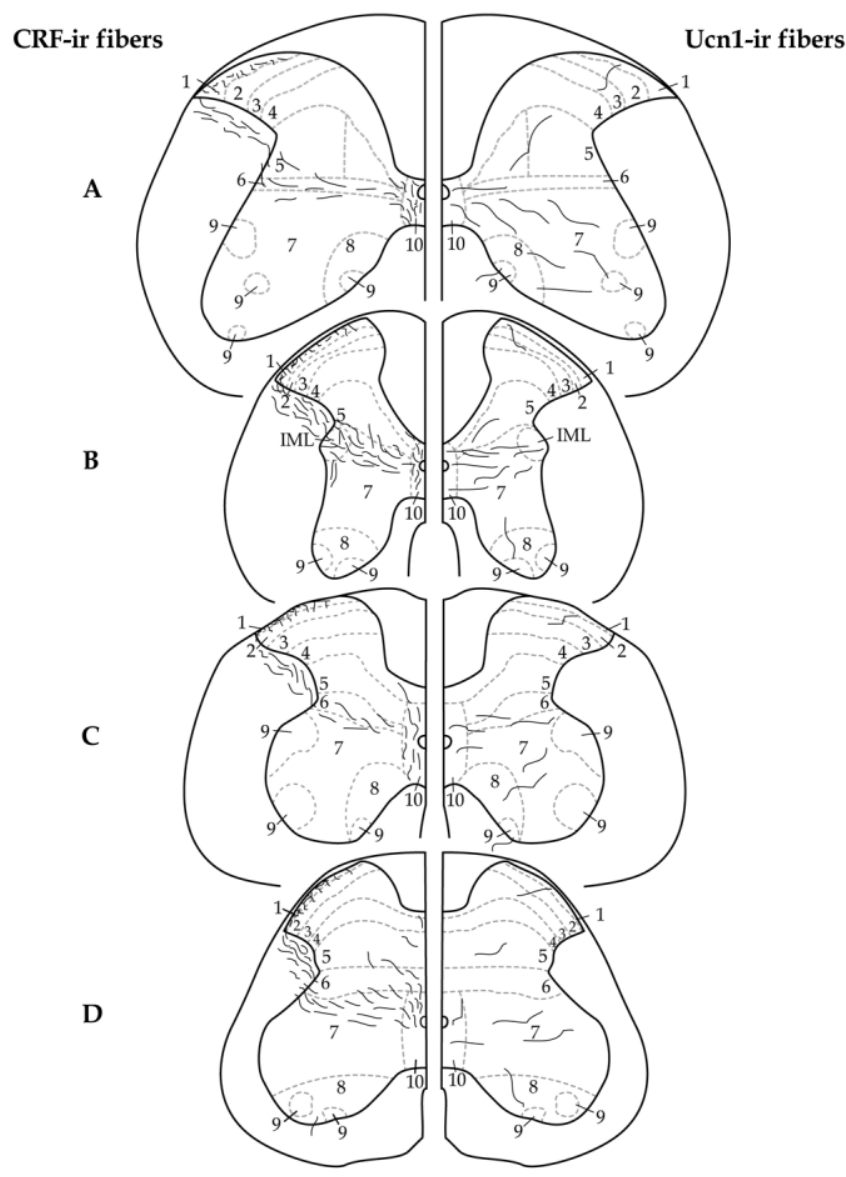

Fig. 2. Schematic drawing of coronal sections of the mouse spinal cord, showing the distribution of CRF- and Ucn1-immunoreactive (ir) fibers in (A) the cervical (segment C7), (B) thoracic (T3), (C) lumbar (L5), and (D) sacral (S1) parts. IML, intermediolateral column.

horn, CRF-ir axons were present in laminae I and II, with numerous varicose fibers traveling in a dorsal-ventral direction. In the thoracic and lumbar parts of the cord, a dense accumulation of CRF-ir varicose fibers was seen in the sympathetic IML (Fig. 3B,C) and in the sacral part in the parasympathetic column (SPN; Fig. 3E). Bands of CRF-ir fibers appeared to course through lamina VII between the IML and/or SPN and lamina X. A dense band of fibers was present close to the central canal (lamina X; Fig. 3C). These CRF fibers frequently crossed the midline dorsal and ventral around the central canal. Occasionally, fibers could be observed in the ventral horn (Fig. 3F). These data are summarized in Table 1 and in Figure 2.

\section{Ucn1 fiber distribution}

The fibers were typically long and beaded, exhibiting irregularly spaced varicosities of variable size (Fig. 4A,D), some of which gave rise to bouton-like terminals. The fibers ran both dorsoventrally projecting between two or more laminae and horizontally (Fig. 4A-E). The strong accumulation of Ucn1-ir fibers was consistently seen in the intermediate gray (lamina VII) and the IML in thoracic (Fig. 4A) and lumbar parts, and the fibers extended into the central gray (lamina X; Fig. 4A,D). In the dorsal part, a few coarse fibers were present in the marginal zone (lamina I; Fig. 4E). Low to moderate numbers of fibers were detected in the ventral horn, including a few fibers that possibly contacted motoneurons (Fig. 4B,C). Furthermore, scattered fibers running from the white to the gray matter were visible in lamina IX. These data are summarized in Table 1 and Figure 2.

\section{CRF1 and CRF2 mRNA distributions}

Both CRFR mRNAs were seen throughout the spinal cord, in neurons. Non-neuronal elements were never found to be positive. With the sense probes (controls), no hybridization signals were visible. Hybridization signals were always in perikarya, with variable staining intensity. Although CRF1 and CRF2 mRNAs showed partly overlapping distributions, they exhibited clear differences in particular areas of the spinal cord (Table 1).

CRF1 mRNA distribution. In the cervical part (Fig. 6A), CRF1 mRNA was present in neuronal perikarya in laminae III-VIII, with the lowest expression in lamina III (Fig. 7A), whereas most labeled neurons were present in laminae VII and VIII (Fig. 7B). In the thoracic part (Fig. $6 \mathrm{~B})$, labeled neurons were seen in all laminae except lamina IX. The lowest number of positive neurons and the weakest signals were observed in the superficial laminae of the dorsal horn (I-IV), and the highest number of labeled neurons was seen in laminae V and VII and the IML (Fig. 7C). The lumbar part (Fig. 6C) exhibited the highest number of labeled neurons in laminae VII and VIII and slightly lower numbers in laminae III-VI. No evidence was found for labeled neurons in the most superficial laminae in this part of the cord (Fig. 7D). In the sacral part (Fig. 6D), a few positive neurons occurred in the dorsal horn (laminae III-V), but strong signals occurred in laminae VII and VIII. There were no labeled neurons in lamina X (Fig. 7E), but some CRF1 mRNA-positive neurons were present in lamina IX. These data are summarized in Table 1 and Figure 5.

CRF2 mRNA distribution. In the cervical part (Fig. 6E), CRF2 mRNA-containing neurons occurred in laminae IV-X (Fig. 8A), with the strongest signals in laminae VII-IX (Fig. 8B). As to the thoracic part (Fig. 6F), in all laminae hybridization signals were observed with similar high strength, except for the two most superficial laminae, I and II, in the dorsal horn, where labeling intensity was less strong, and lamina III, which exhibited a moderate signal only. Furthermore, the IML showed strong hybridizations. In the lumbar part (Fig. 6G), labeled neurons were present in all laminae, with low densities in laminae I and II. In laminae III-VIII (Fig. 8C) and around the central canal (lamina X; Fig. 8D), neurons exhibited a particularly intense labeling, which was stronger than the labeling seen in any other part and lamina of the cord. In the sacral part (Fig. 6H), except for laminae I and II (Fig. $8 \mathrm{E})$, all laminae exhibited substantial hybridization, with the strongest labeling in lamina IX. For a summary of these data, see Table 1 and Figure 5.

\section{CRFR protein distribution}

The antiserum used in this study for CRFR detection was directed against the intracellular C-terminus of the receptor proteins. Because this region is highly homologous between CRF1 and CRF2, the serum does not differentiate between these receptor types (Sehringer et al., 2000; Dautzenberg and Hauger, 2002; Kimura et al., 
TABLE 1. Distribution of CRF1 and CRF2 mRNA (Mouse) and CRF and Ucn1 Immunoreactivity (Rat) in the Spinal Cord ${ }^{1}$

\begin{tabular}{|c|c|c|c|c|c|}
\hline Spinal cord part & $\begin{array}{l}\text { Laminae of } \\
\text { Rexed }\end{array}$ & $\begin{array}{c}\text { CRF1 } \\
\text { mRNA }\end{array}$ & $\begin{array}{l}\text { CRF2 } \\
\text { mRNA }\end{array}$ & $\begin{array}{l}\text { CRF-ir } \\
\text { fibers }\end{array}$ & $\begin{array}{l}\text { Ucn1-ir } \\
\text { fibers }\end{array}$ \\
\hline \multicolumn{6}{|l|}{ Cervical } \\
\hline \multirow[t]{5}{*}{ Dorsal horn } & I-II & - & - & +++ & + \\
\hline & III & + & - & - & + \\
\hline & IV & ++ & ++ & - & - \\
\hline & $\mathrm{V}$ & ++ & + & ++ & - \\
\hline & VI & + & + & + & - \\
\hline Intermediate zone & VII & +++ & +++ & +++ & +++ \\
\hline \multirow[t]{2}{*}{ Ventral horn } & VIII & ++ & +++ & - & + \\
\hline & IX & - & +++ & - & + \\
\hline Around central canal & $\mathrm{X}$ & - & ++ & +++ & ++ \\
\hline \multicolumn{6}{|l|}{ Thoracic } \\
\hline \multirow[t]{4}{*}{ Dorsal horn } & I-II & + & + & +++ & + \\
\hline & III & ++ & + & - & - \\
\hline & IV & ++ & ++ & - & - \\
\hline & $\mathrm{V}$ & +++ & ++ & + & + \\
\hline \multirow[t]{2}{*}{ (only T1) } & VI & + & ++ & + & \\
\hline & IML & +++ & +++ & +++ & ++ \\
\hline Intermediate zone & VII & +++ & +++ & ++ & ++ \\
\hline \multirow{2}{*}{ Ventral horn } & VIII & ++ & ++ & - & - \\
\hline & IX & - & ++ & - & + \\
\hline Around central canal & $\mathrm{x}$ & + & +++ & +++ & ++ \\
\hline \multicolumn{6}{|l|}{ Lumbar } \\
\hline \multirow[t]{5}{*}{ Dorsal horn } & I-II & - & - & +++ & + \\
\hline & III & + & ++ & - & + \\
\hline & IV & ++ & ++ & - & - \\
\hline & $\mathrm{V}$ & ++ & ++ & + & - \\
\hline & VI & ++ & ++ & + & - \\
\hline (only from L1 to L3) & IML & ++ & +++ & +++ & +++ \\
\hline Intermediate zone & VII & +++ & +++ & +++ & +++ \\
\hline \multirow{2}{*}{ Ventral horn } & VIII & +++ & ++ & - & - \\
\hline & IX & - & +++ & - & + \\
\hline Around central canal & $\mathrm{X}$ & - & +++ & +++ & ++ \\
\hline \multicolumn{6}{|l|}{ Sacral } \\
\hline \multirow[t]{4}{*}{ Dorsal horn } & I-II & - & - & +++ & + \\
\hline & III & - & ++ & - & - \\
\hline & IV & + & ++ & - & - \\
\hline & $\mathrm{V}$ & + & ++ & + & + \\
\hline (only S1) & VI & - & + & ++ & - \\
\hline Intermediate zone & VII & ++ & +++ & +++ & ++ \\
\hline \multirow[t]{2}{*}{ Ventral horn } & VIII & +++ & +++ & - & + \\
\hline & IX & + & +++ & - & + \\
\hline Around central canal & $\mathrm{x}$ & - & ++ & +++ & ++ \\
\hline
\end{tabular}

${ }^{1}$ Semiquantitative scores of the density of positively labeled cells: - , absent or very rare;,+ low; ++ , moderate; +++ , high. Columns 3 and 4 give mRNA data in the mouse, and columns 5 and 6 give immunoreactivity (ir) data in the rat. IML, intermediolateral column.

2002). Therefore, we consider the presence of immunostaining with this anti-CRFR serum as indicative for the presence of CRF1 or CRF2 or of both.

CRFR-ir neurons were widely but selectively distributed throughout the spinal cord. In general, the distribution fit well with the combined distributions of CRF1 and CRF2 mRNAs as observed with in situ hybridization. All four parts of the spinal cord contained CRFR-ir neurons in the gray matter (Fig. 9A-D). Most of these neurons occurred in the dorsal horn, primarily in laminae III-VII and $\mathrm{X}$. In lamina I, a punctate-like staining was occasionally seen at some distance from neuronal perikarya (Fig. 10A), possibly indicating the presence of CRFR on dendrites rather than on cell bodies. In addition, CRFR-ir was clearly visible in the white matter immediately lateral to the marginal zone in the dorsomedial part of the lateral funiculus (reticular formation; Fig. 10B). In the thoracic and lumbar parts of the spinal cord, CRFR-ir was found in the IML (Fig. 9B). Many stained cells were observed in lamina $\mathrm{X}$, and large numbers of immunoreactive neurons also occurred in the ventral horn (lamina VIII-IX; Fig. 9A-D), the largest and most intensely stained neurons being located in lamina IX (Fig. 10C). In the sacral part of the cord, immunoreactivity was restricted to the ventral horn and to the area directly around the central canal. The pattern of CRFR-ir suggested that CRFR were present on the plasma membrane of neuronal perikarya (Fig. 10D).

\section{Relationship of CRF and Ucn1 fibers with CRFR-ir neurons}

To study whether CRF-ir and Ucn1-ir fibers contact CRFR-containing neurons, double-labeling immunofluorescence was performed. In laminae VII and X in particular, various CRF- and Ucn1-ir fibers were seen in close proximity to CRFR-ir cells (Fig. 11A-I).

\section{DISCUSSION General considerations}

Up to now, only in the rat have CRF-ir and Ucn1-ir fibers been described in the spinal cord, and only fragmentary evidence has been available for the presence of CRF receptors and CRF2 mRNA in the spinal cord. The present study provides the first description of the distribution of $\mathrm{CRF}$ and Ucn1 fibers, mRNAs of CRF1 and CRF2, and CRFR protein in the mouse spinal cord at the neuronal level. The distributions will be discussed and the CRFR distributions compared with those of CRF and Ucn1. Finally, possible functional implications of our results will be considered.

\section{CRF and Ucn1 fiber distributions}

We found CRF-ir fibers in all four parts of the mouse spinal cord in similar patterns, mainly in the superficial 

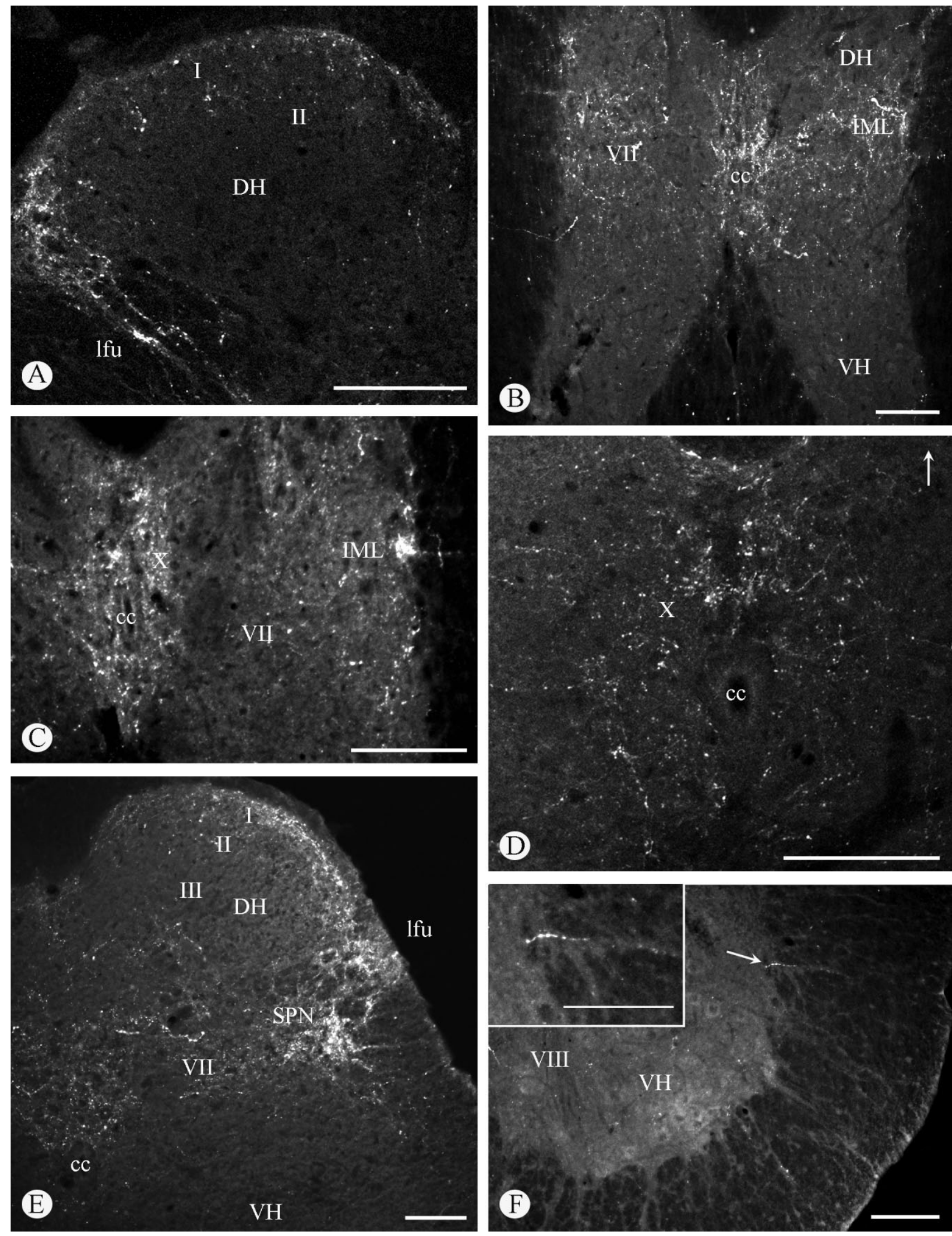

Fig. 3. CRF-ir fibers shown by immunofluorescence labeling in coronal sections of mouse spinal cord, in the dorsal horn (DH) in (A) the cervical part in lamina I of Rexed and the dorsomedial part of the lateral funiculus (lfu), (B,C) the thoracic part between the intermediate gray (lamina VII), the sympathetic intermediolateral column (IML), and the area surrounding the central canal (cc; lamina X), (D)

around the central canal, frequently crossing the midline dorsoventrally, (E) the sacral part in lamina I, VII, and X, lfu, and sacral parasympathetic column (SPN), and (F) occasionally the ventral horn. Enlargement in $\mathrm{F}$ shows detail of CRF-ir fiber in ventral horn $(\mathrm{VH}$; arrow). Scale bar $=100 \mu \mathrm{m}$ in $\mathrm{A}-\mathrm{F}$. 

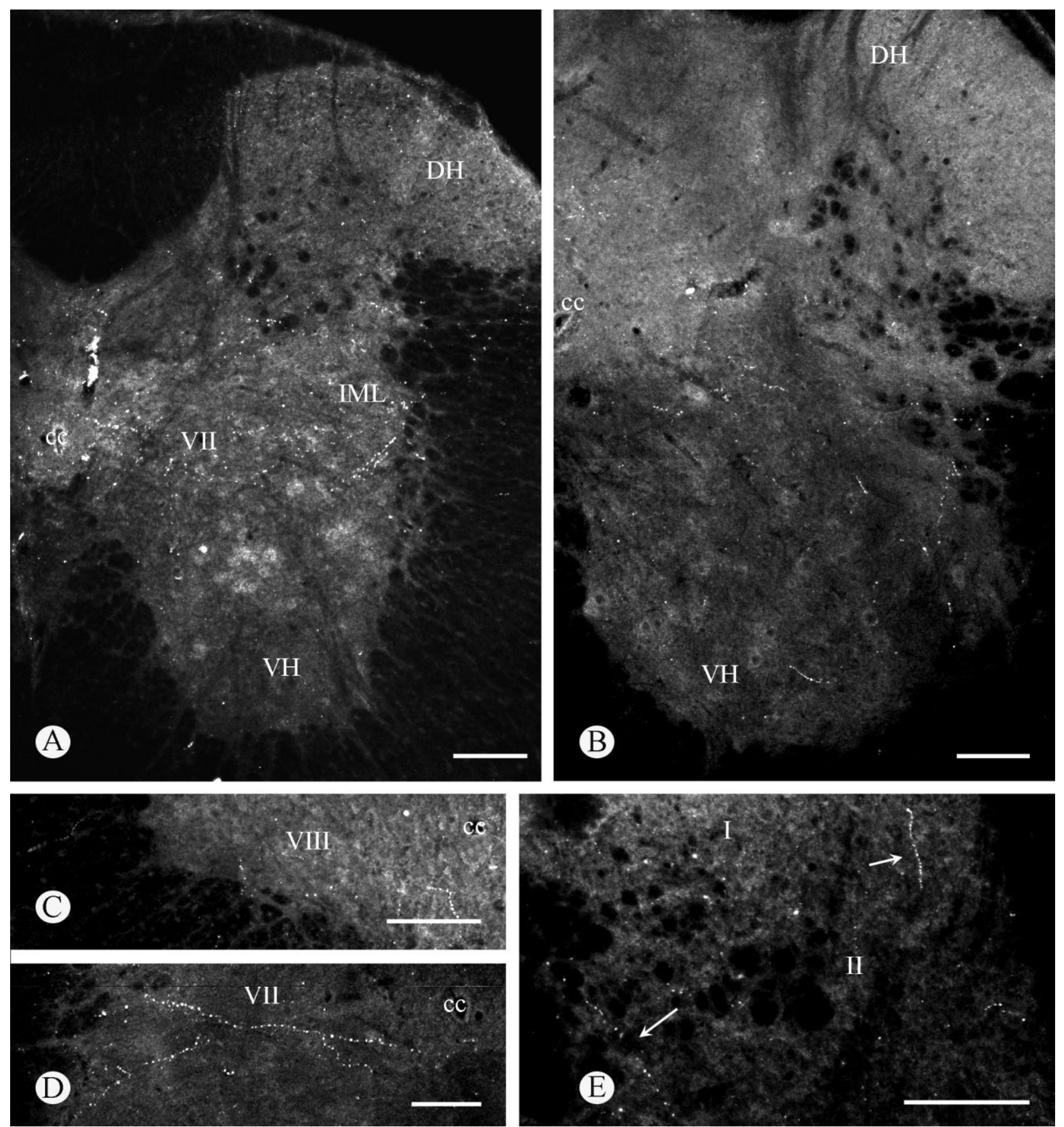

Fig. 4. Ucn1-ir fibers shown by immunofluorescence labeling predominate in (A) laminae VII and X and the sympathetic intermediolateral column (IML) of the thoracic part but have a low to moderate density in the ventral horn (VH) of the sacral part (B). C: Occasionally Ucn1-ir fibers run from the white to the gray matter. D: Particularly

long fibers run across the intermediate gray (lamina VII) in the direction of the central canal (cc). E: Coarse fibers (arrows) are present in the marginal zone of the dorsal horn (DH). Scale bar $=100$ $\mu \mathrm{m}$ in $\mathrm{A}-\mathrm{E}$.

laminae, in laminae V-VII, around the central canal, in the reticular formation of the white matter, and in the dorsal part of the lateral funiculus; thus the distribution of these fibers in the mouse spinal cord closely resembles that observed in the rat spinal cord (Merchenthaler et al., 1983). Similarly, because Ucn1-ir oc-

curred in all four parts of the mouse spinal cord, in a pattern similar in all four parts, mainly occurring in lamina VII and around the central canal, the distribution of Ucn 1 fibers also closely resembles that found in the spinal cord of the rat (Bittencourt et al., 1999). 


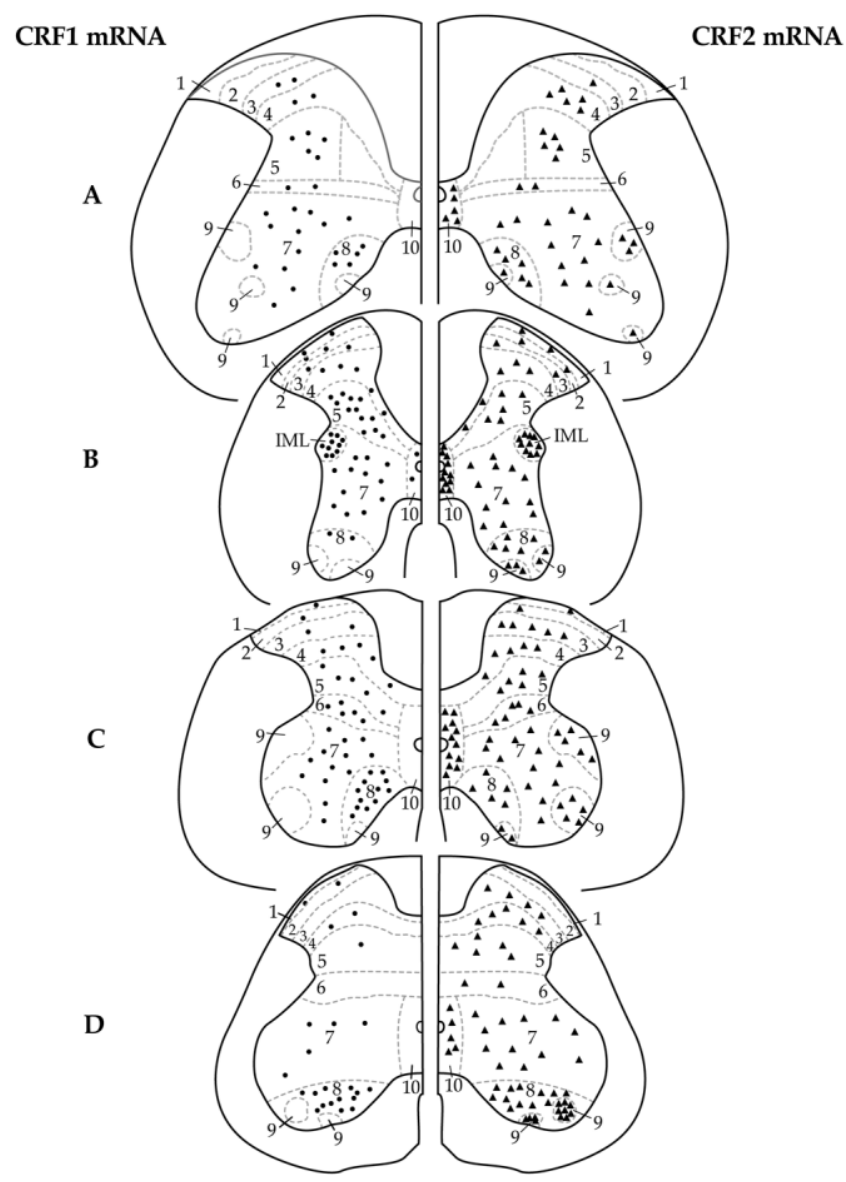

Fig. 5. Schematic drawing of coronal sections showing the distribution of cells expressing CRF1 mRNA (solid circles) and CRF2 mRNA (solid triangles) in (A) the cervical (segment C7), (B) thoracic (T3), (C) lumbar (L5), and sacral (S1) (D) parts of the mouse spinal cord. IML, intermediolateral column.

Apparently, the distributions of CRF and Ucn1 fibers only partly overlap, and some areas (laminae) of the spinal cord exhibited only one of these fiber types. These distributions in the spinal cord are essentially the same as those in rat (Merchenthaler et al., 1983; Bittencourt et al., 1999), which also holds for the distributions of CRF and Ucn 1 in the mouse and rat brain (Keegan et al., 1994; Weitemier et al., 2005). The dense varicosities of the CRF and Ucn 1 fibers may point to local storage of neuropeptide in axonal swellings and/or to the presence of presynaptic peptide-filled terminals along the fiber, which would indicate a regulatory action of these peptides. Electron microscopy may help to elucidate the significance of the varicosities and to relate the distributions of the fibers found in this study to those of their receptors, giving us insight into the possible regulatory roles of $\mathrm{CRF}$ and Ucn 1 in the spinal cord (see below).

\section{Different CRF1 mRNA and CRF2 mRNA distributions}

In this study we used nonradioactive in situ hybridization to assess the presence of CRF1 and CRF2 mRNAs, and we found hybridization signals with CRF1 and CRF2
mRNA probes exclusively in neuronal perikarya of the mouse spinal cord. For various reasons, we feel confident as to the reliability/specificity of our technical approach and of our conclusions with respect to the distribution of the two CRFR mRNAs in the mouse spinal cord. First, the absence of background staining and staining with sense probes indicates that the signals specifically reveal the presence of CRF1 and CRF2 mRNAs. Second, in our previous demonstration with the same method and probes, the two CRF receptor mRNAs had different, nonoverlapping distributions in the mouse brain (Korosi et al., 2006) that were in full agreement with the distributions described by Van Pett et al. (2000). Third, our present data show different distributions in the spinal cord (see below).

This is the first report on the presence of CRF1 mRNA in the mammalian spinal cord and the first detailed description of the distribution of CRF1 mRNA and CRF2 mRNA in the mouse spinal cord. We observed the presence of these mRNAs in all four parts of the cord and in all laminae of Rexed. Our data support the hypothesis that the distributions of the two receptor mRNAs are not identical, as appears from the following observations. CRF2 mRNA has a wider distribution than CRF1 mRNA, occurring throughout the spinal cord in all laminae, with the exception of lamina I-II, where it was not found in the cervical, lumbar, and sacral parts, and of laminae III, where it was not found in the cervical part. In contrast, CRF1 mRNA is almost completely restricted to laminae III-VIII, with the exception of the thoracic part, where it occurs in laminae I-II and X, and the sacral part, where it was not found in lamina VI.

Our finding of a predominance of CRF2 mRNA in lamina IX extends electrophysiological evidence for the presence of CRF receptors in motoneurons of the rat ventral horn (Bell and De Souza, 1988). Furthermore, our findings provide evidence for the suggested presence of CRF receptors in the IML and in laminae I-VII and X. This suggestion was based on the fact that experimentally applied $\mathrm{CRF}$ and Ucn1 increase the number of cFos-positive cells in the IML and in laminae I-VII and X (Maillot et al., 2003). In these areas we show the presence of both CRF receptor mRNAs and CRFR-ir. In fact, our immunocytochemical findings in regard to CRFR support our view that the occurrence of CRFR mRNAs is indicative of the presence of CRFR proteins. This will be explained below.

\section{CRFR distributions in relation to CRF and Ucn 1 occurrence}

The observed CRFR-ir distribution is generally congruent with the distributions of CRF1 and CRF2 mRNA that we found (Table 1). CRFR-ir seems to be largely confined to the plasma membrane, which is consistent with the fact that CRF1 and CRF2 are G-protein-coupled, plasma membrane-bound proteins (Chang et al., 1993; Perrin et al., 1993). Minor differences between these CRFR protein and mRNA distributions may be caused, for example, by differences in the dynamics of receptor transcription and translation and/or differences in cytoplasmic CRFR mRNA and protein transport and turnover.

Another point of importance is the part of the neuron that receives a synaptic input, specifically, the CRFR-ir dots in lamina I, which lacks CRF receptor mRNAs in the cervical, lumbar, and sacral parts. These dot-like stainings could be on the long dendrites of the "antenna-like 


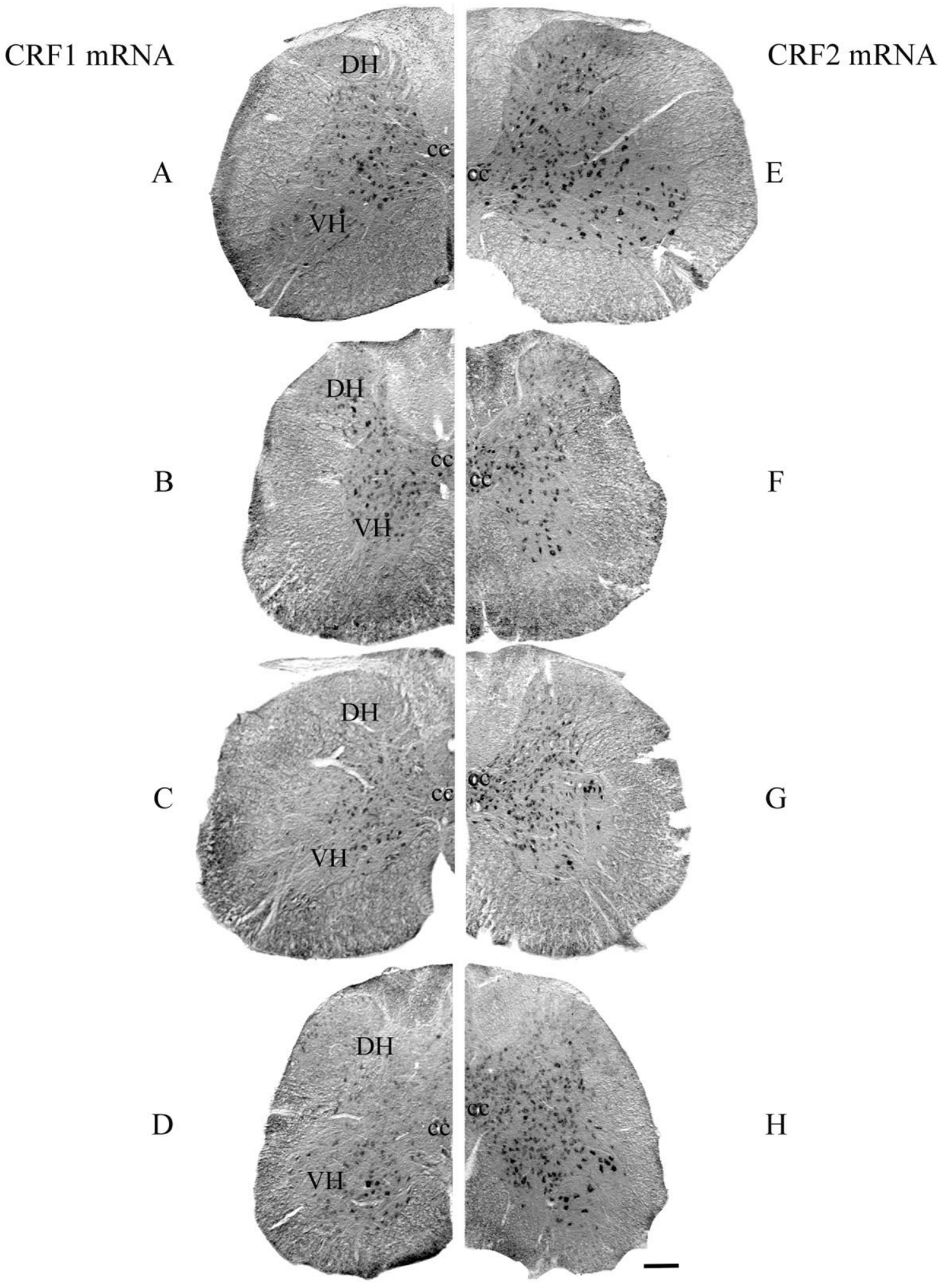

Fig. 6. Distributions of (A-D) cell bodies expressing CRF1 mRNA and (E-H) and CRF2 mRNA in the (A,E) cervical (C7 and C5, respectively), (B,F) thoracic (T3), (C,G) lumbar (L5), and (D,H) sacral (S1) parts. cc, central canal; DH, dorsal horn; VH, ventral horn. Scale bar $=100 \mu \mathrm{m}$ in H (applies to A-H). 

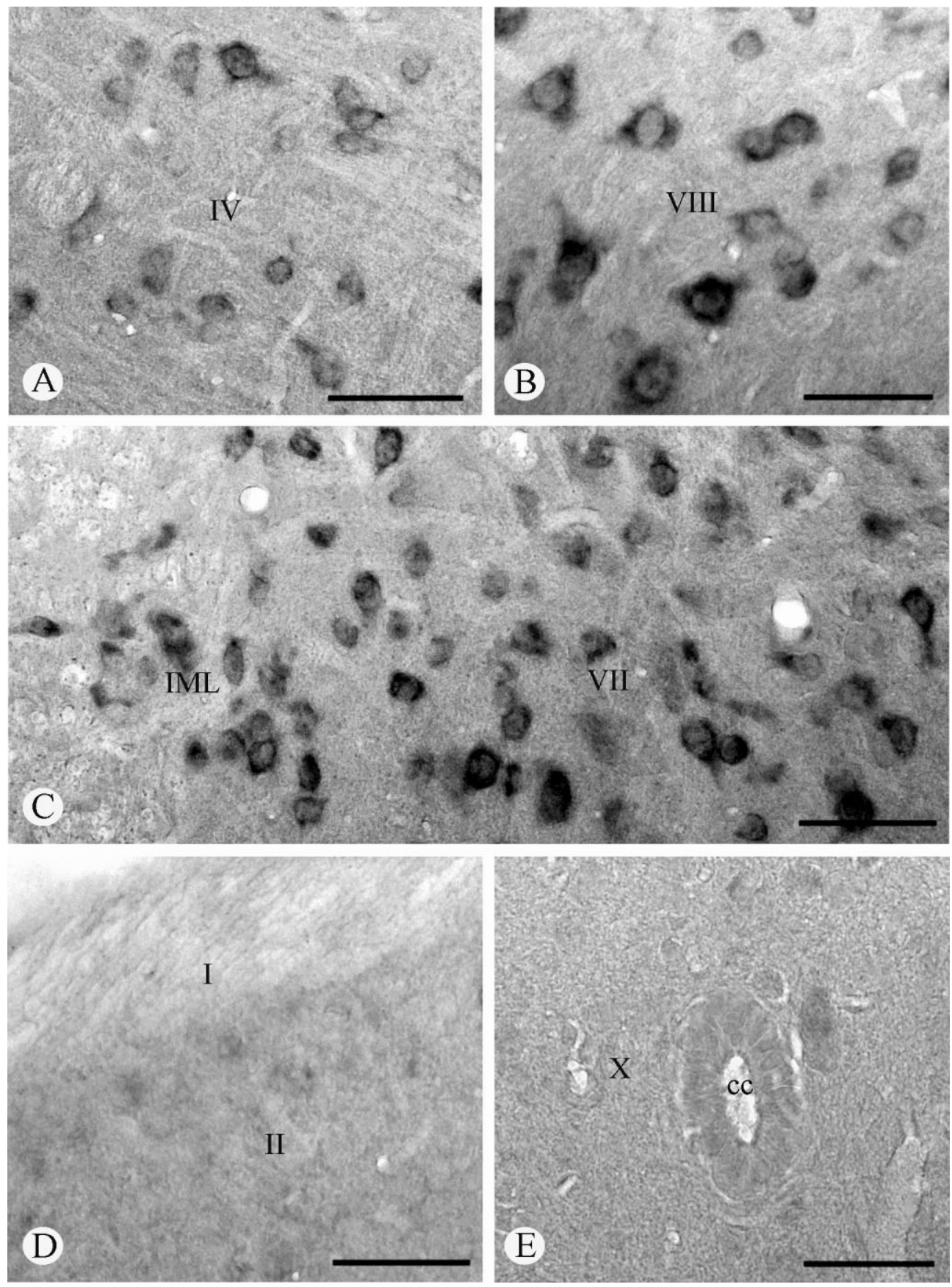

Fig. 7. CRF1 mRNA in (A) lamina IV and (B) lamina VIII in the cervical part and (C) the intermediate gray (lamina VII) and sympathetic intermediolateral column (IML) in the thoracic part. No CRF1 mRNA-positive neurons occur in laminae I-II of the lumbar (D) and around the central canal (cc) lamina $\mathrm{X}$ of the sacral parts $(\mathbf{E})$. Scale bar $=50 \mu \mathrm{m}$ in A-E.

neurons" that have their cell bodies in lamina IV (Skofitsch et al., 1985; Bell and De Souza, 1988; Grant and Koerber, 2004; De Souza, 1995). A presence of CRFR in lamina I fits with the previously described binding of CRF in this lamina (Skofitsch et al., 1985; Bell and De Souza, 1988; De Souza, 1995).

From comparing CRF and Ucn1 fiber distributions with CRFR mRNA and CRFR protein distributions, it appears that CRF, Ucn1, and both CRF receptors occur together in every part of the spinal cord. Such similar distributions, however, are hardly useful to generate a hypothesis as to the possible functional relation between a specific ligand and a given receptor. For that purpose, we need to take a closer look at the level of the individual peptides and receptors in each of the specific laminae, taking both strength of mRNA expression and strength of ligand im- 

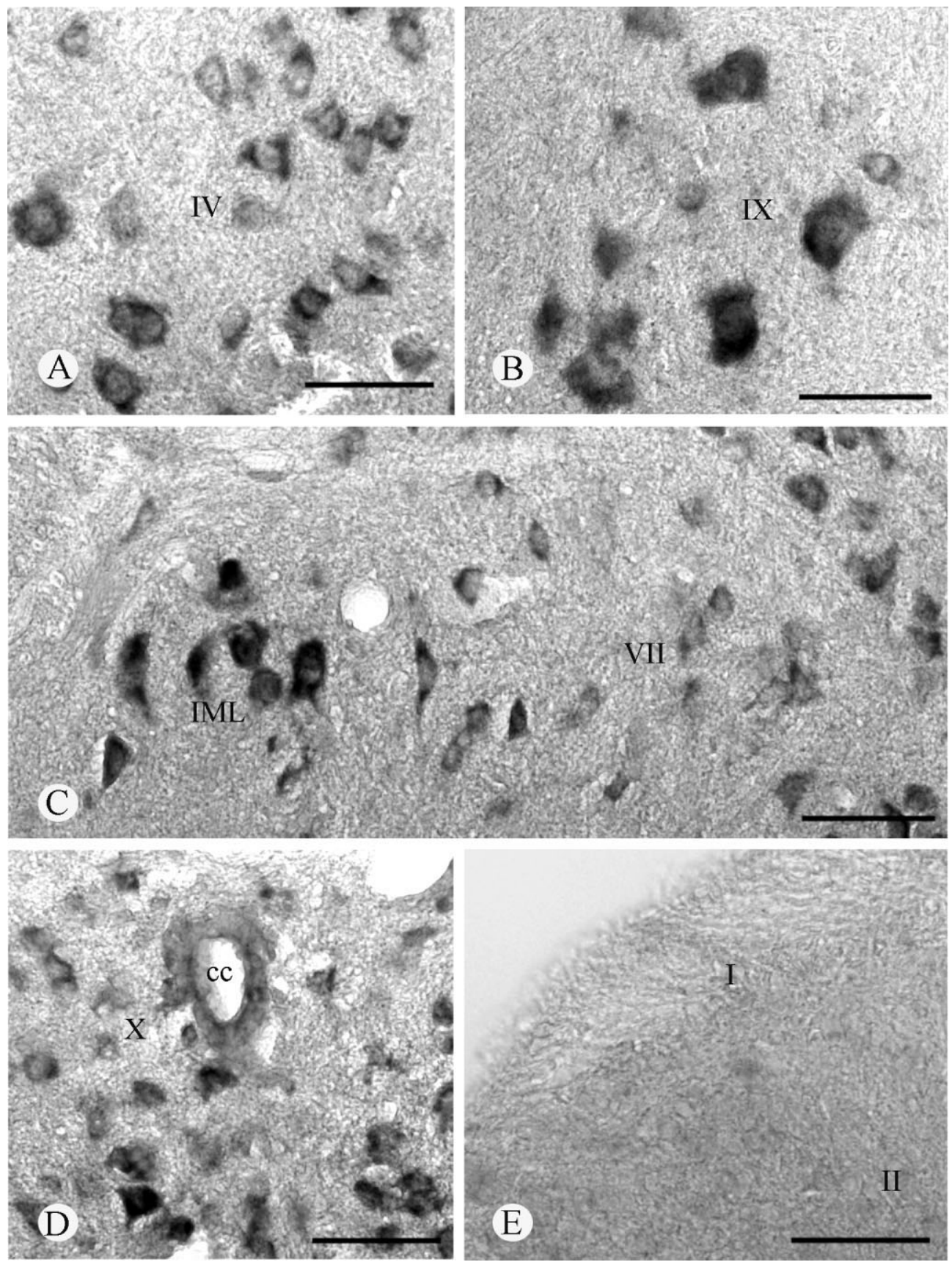

Fig. 8. CRF2 mRNA expression in laminae IV (A) and IX (B) in the cervical part and in the intermediate gray (lamina VII) and sympathetic intermediolateral column (IML) in the thoracic part (C) and around the central canal (cc) in lamina X, in the lumbar part (D). E: No CRF2 mRNA-positive neurons occur in laminae I and II in the sacral part. Scale bar $=50 \mu \mathrm{m}$ in A-E.

munostaining into account. Two factors are of interest: 1) matching: the distribution of one or both ligands overlaps with that of one or both receptor mRNAs (co-distribution); and 2) mismatching: receptor $\mathrm{mRNA}(\mathrm{s})$ but no ligands are present. These factors are considered below in detail.

1. Matching. As Table 1 shows, the strongest codistribution of the two receptor mRNAs with both ligands occurs in lamina VII of all parts of the spinal cord and in the IML. Furthermore, all parts exhibit co-distribution of CRF with CRF1 mRNA and with CRF2 mRNA in lamina $\mathrm{V}$ and VI and of Ucn1 with CRF2 mRNA in lamina IX. Some co-distribution is restricted to particular regions, such as the co-distribution of both receptor mRNAs and both ligands in laminae I-II and X of the thoracic part and the co-distribution of CRF and Ucn1 with CRF2 mRNA alone in lamina $\mathrm{X}$ of the cervical, lumbar, and sacral parts. 

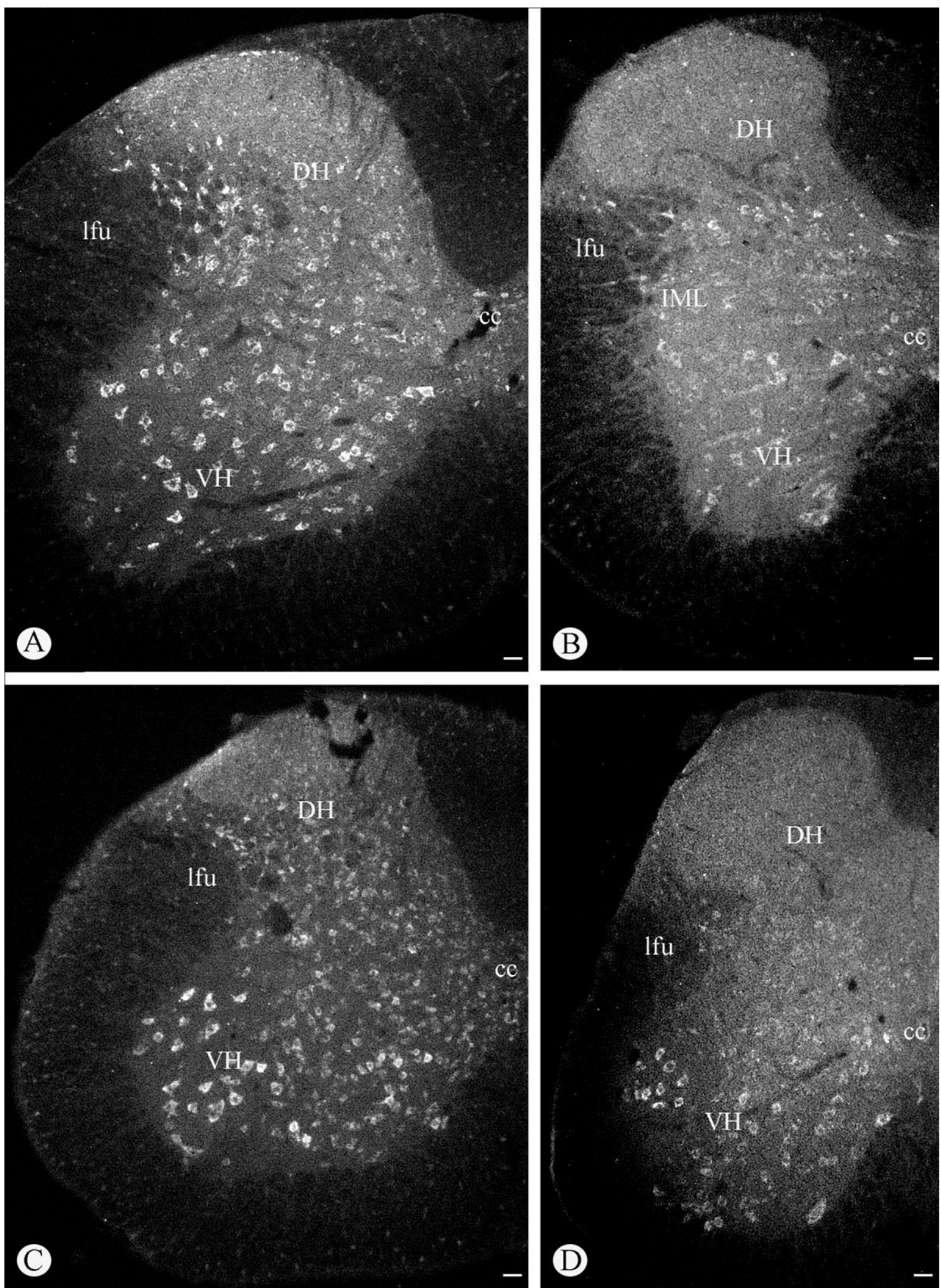

Fig. 9. CRFR-ir neurons in (A) cervical (C7), (B) thoracic (T3), (C) lumbar (L5), and (D) sacral (S1) parts. cc, central canal; DH, dorsal horn; IML, sympathetic intermediolateral column; lfu, lateral funiculus; VH, ventral horn. Scale bar $=50 \mu \mathrm{m}$ in A-D. 

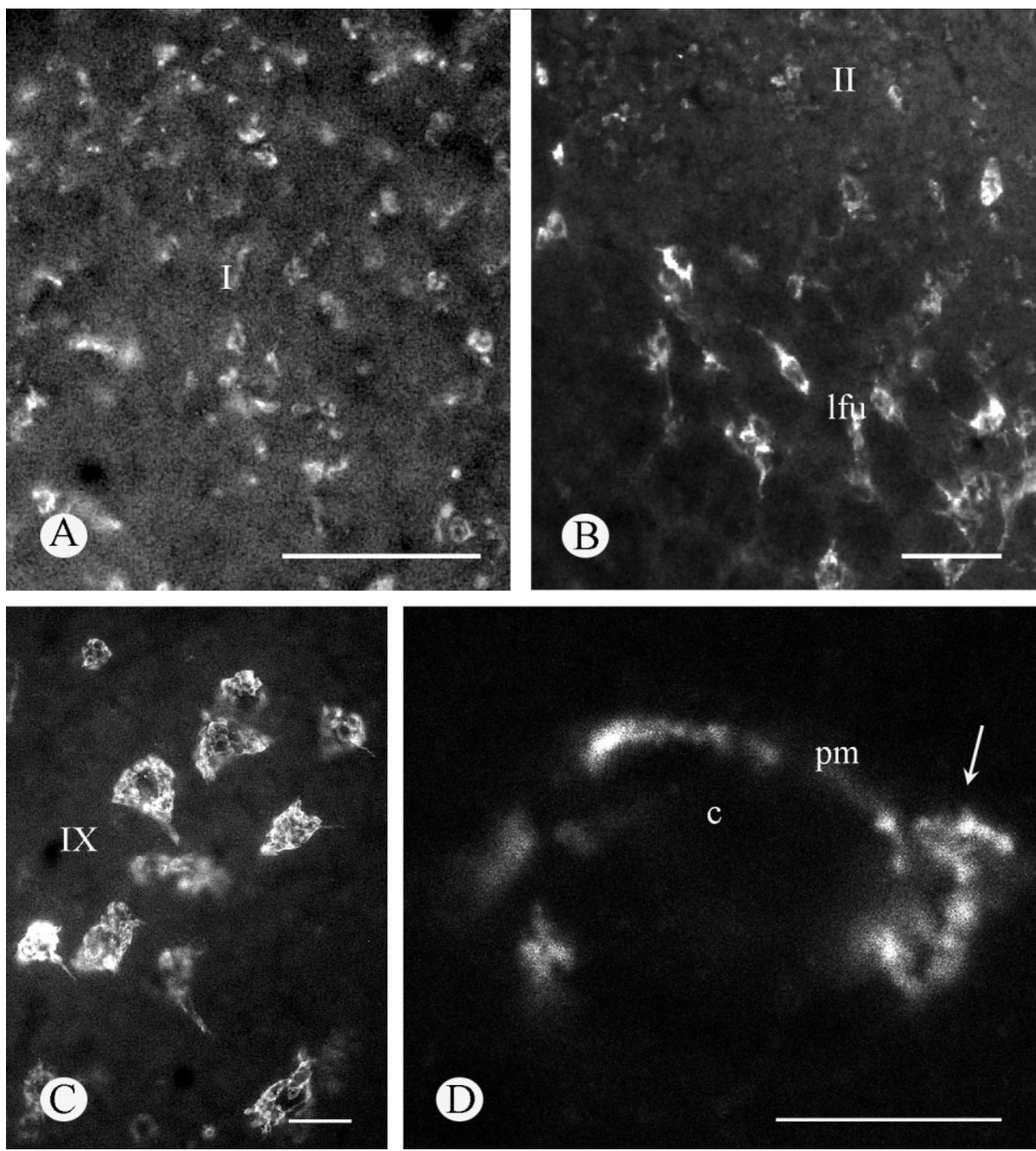

Fig. 10. CRFR-ir neurons in (A) laminae I and II with a punctate-like staining and (B) the dorsomedial lateral funiculus (lfu). C: Note the large motoneurons in lamina IX. D: CRFR-ir pattern suggests receptor presence in plasma membrane $(\mathrm{pm})$. Arrow indicates the initial segment of the apical dendrite. c, cytoplasm. Scale bar $=100 \mu \mathrm{m}$ in A-C; $10 \mu \mathrm{m}$ in D.

Clearly, these data are only correlative and do not provide conclusive evidence that the ligands are actually released and bind these receptors. Nevertheless, it should be noted that, for instance, the exclusive presence of Ucn 1 and CRF2 mRNA in lamina IX is in line with the high affinity of the CRF2 receptor for Ucn1 (Vaughan et al., 1995).

2. Mismatching. In some laminae where we show the presence of CRF receptor mRNAs, no CRF or Ucn 1 seemed to occur (Merchenthaler et al., 1983; Schipper et al., 1983; Swanson et al., 1983; Bittencourt et al., 1999; Puder and Papka, 2001). This holds for laminae III, IV, VIII, and IX in the case of CRF and for laminae III-VI and VIII with regard to Ucn1. Assuming that the mRNAs found in these layers are indicative of the local presence of their respective receptor proteins, ligands other than $\mathrm{CRF}$ and Ucn1 might act on these receptors. Candidate ligands are two other members of the CRF-family, Ucn2 and Ucn3. Indeed, in both mouse and rat brain the distribution of Ucn2 mRNA and in the mouse brain the distribution of Ucn3
mRNA reveal a high degree of overlap with the distribution of CRF2 mRNA. Ucn2 mRNA expression has been shown in the mouse and rat spinal cord (Reyes et al., 2001). Both Ucn 2 and Ucn3 have been suggested to be involved in the regulation of autonomic functions (Lewis et al., 2001; Reyes et al., 2001), possibly in the spinal cord.

By double immunofluorescence we demonstrate CRF-ir and Ucn1-ir fibers in close proximity to CRFR-ir neurons, indicating possible synaptic contacts between these fibers and $\mathrm{CRF}$ receptors. Electron microscopy is required to confirm the presence of such contacts.

\section{Functional considerations}

On the basis of our mapping and semiquantitative assessment of the presence and strength of expression of the two $\mathrm{CRF}$ receptor mRNAs, and in view of their laminaspecific co-distribution with CRF- and Ucn1 fibers, some suggestions may be made as to the functional significance of CRF1 and CRF2 in the mouse spinal cord. 

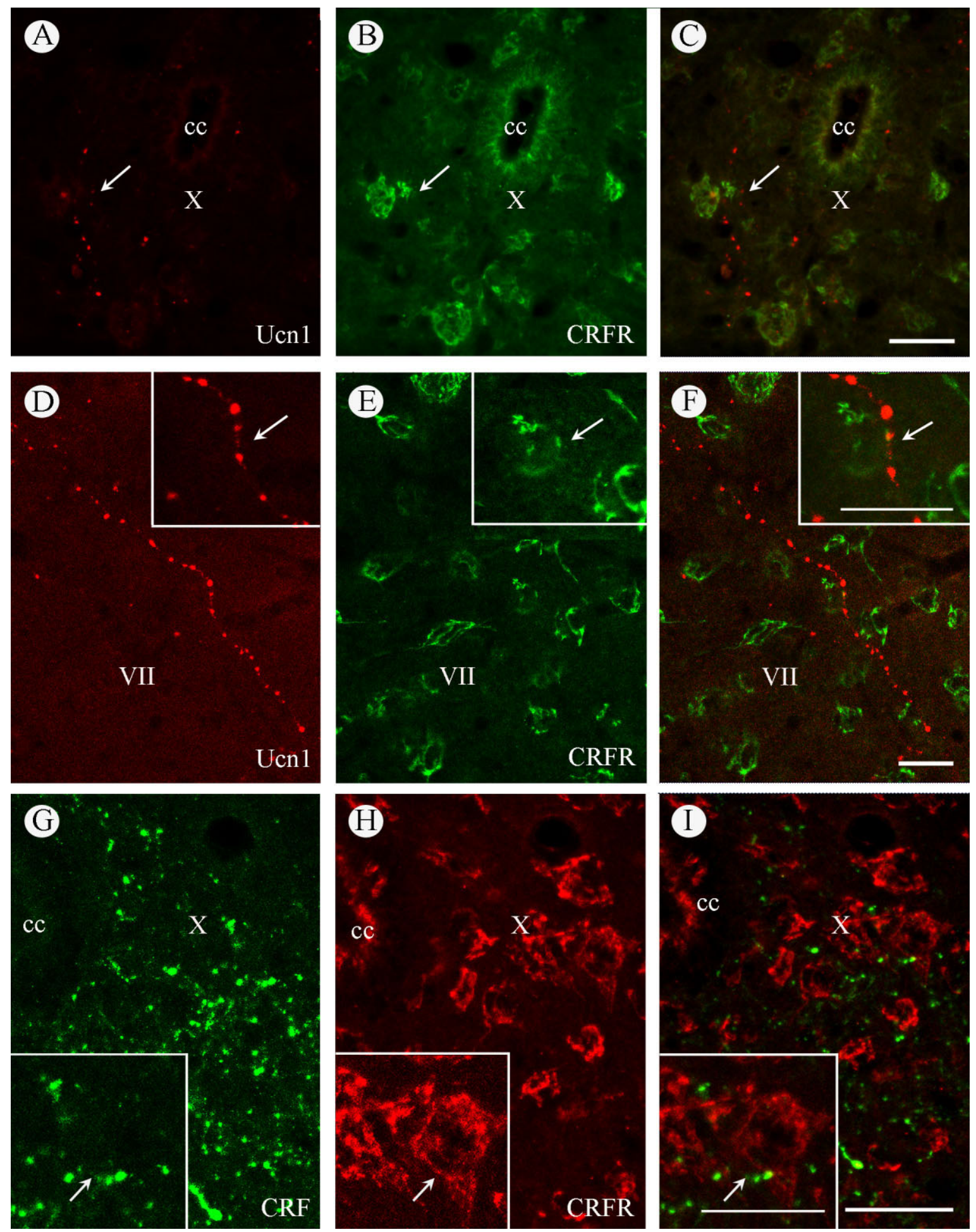

Fig. 11. Double immunofluorescence labeling of (A-F) Ucn1 fibers and CRFR and of (G-I) CRF and CRFR. Ucn1-ir (A-C) and CRF-ir (G-I) fibers occur in close proximity to CRFR-ir neurons in lamina X D-F: Detail of long, beaded Ucn1 fiber possibly synaptically contact-

ing CRFR-ir neurons in lamina VII. cc, central canal. Scale bar $=50$ $\mu \mathrm{m}$ in $\mathrm{C}$ (applies to A-C), F (applies to D-F), inset to F (applies to insets to D-F), I (applies to G-I); $25 \mu \mathrm{m}$ in inset to I (applies to insets to $\mathrm{G}-\mathrm{I})$.

Because CRF1 and CRF2 mRNAs occur throughout the spinal gray matter, it may be expected that the CRF receptors and their ligands influence both sensory and

motor systems. For example, the predominance of CRF1 and CRF2 mRNAs in lamina VII and in the IML, both containing spinal preganglionic autonomic neurons 
(Grant and Koerber, 2004), indicates that CRF1 and CRF2 play a role in mediating sympathetic actions of CRF and Ucn1. Furthermore, the abundance of CRF-ir and Ucn1-ir terminals in lamina VII and in the IML in mouse (our study) and in rat (Merchenthaler et al., 1983; Bittencourt et al., 1999; Puder and Papka, 2001) supports the idea that autonomic actions of CRF and Ucn 1 are mediated by these spinal cord CRF receptors. Obviously, such activities could be crucial contributors to the spinal mechanism by which $\mathrm{CRF}$ and Ucn 1 control the peripheral stress respons.

It is assumed that $\mathrm{CRF}$ controls nociception via $\mathrm{CRF}$ receptors in the spinal cord, because intrathecally administered CRF has an analgesic effect that can be antagonized by intrathecal administration of the CRF receptor antagonist $\alpha$-helical CRF (Larivière and Melzack, 2000; Millan, 2002). Our data support and extend this idea, by revealing the presence of CRF1 and CRF2 mRNAs and CRFR in lamina $\mathrm{V}$, which is known to receive nociceptive input (Song and Takemori, 1991).

We demonstrate the predominance of CRF2 mRNA in lamina $\mathrm{X}$, which may be involved in the control of temperature and visceral nociception (Wang et al., 1999; Grant and Koerber, 2004). There is evidence that CRF and Ucn1 are involved in modulating visceral pain sensitivity (Song and Takemori, 1991; Martinez et al., 2004; Nijsen et al., 2005) and that this modulation takes place via CRF2 (Million et al., 2005). Therefore, the co-distribution of CRF- and Ucn1-ir nerve terminals with CRF2 mRNA in lamina X suggests that the modulation by $\mathrm{CRF}$ and Ucn 1 of visceral pain perception proceeds through CRF2 in this lamina.

Finally, the abundance of CRF2 mRNA in lamina IX, which contains motoneurons that innervate skeletal muscle (Grant and Koerber, 2004), may reflect an involvement of CRF2 and Ucn1 in the modulation of somatic muscle activity. The co-distribution of Ucn1 fibers and CRF2 mRNA in the large motoneurons of the ventral horn (lamina IX) in particular strongly supports the notion that $\mathrm{Ucn} 1$ is involved in modulating motor activities via CRF2.

\section{LITERATURE CITED}

Bale TL, Picetti R, Contarino A, Koob GF, Vale W, Lee KF. 2002. Mice deficient for both corticotropin-releasing factor receptor 1 (CRFR1) and CRFR2 have an impaired stress response and display sexually dichotomus anxiety-like behaviour. J Neurosci 22:193-199.

Bell JA, De Souza EB. 1988. Functional corticotropin-releasing factor receptors in neonatal rat spinal cord. Peptides 9:1317-1322.

Bittencourt JC, Vaughan JM, Arias C, Rissman RA, Vale WW, Sawchenko PE. 1999. Urocortin expression in rat brain: evidence against a pervasive relationship of urocortin-containing projections with targets bearing type 2 CRF receptors. J Comp Neurol 415:285-312.

Brown M. 1986. Corticotropin releasing factor: central nervous system sites of action. Brain Res 399:10-14.

Brown MR, Fisher LA, Rivier J, Spiess J, Rivier C, Vale W. 1982. Corticotropin-releasing factor: effects on the sympathetic nervous system and oxygen consumption. Life Sci 30:207-210.

Chalmers DT, Lovenberg TW, Grigoriadis DE, Behan DP, De Souza EB. 1996. Corticotrophin-releasing factor receptors: from molecular biology to drug design. Trends Pharmacol Sci 17:166-172.

Chang CP, Pearse RV, O'Connell S, Rosenfeld MG. 1993. Identification of a seven transmembrane helix receptor for corticotropin-releasing factor and sauvagine in mammalian brain. Neuron 11:1187-1195.

Chen Y, Brunson KL, Muller MB, Cariaga W, Baram TZ. 2000. Immunocytochemical distribution of corticotropin-releasing hormone receptor type-1 $(\mathrm{CRF}(1))$-like immunoreactivity in the mouse brain: light microscopy analysis using an antibody directed against the C-terminus. J Comp Neurol 420:305-323.
Chung RY, Mason P, Strassman A, Maciewicz R. 1987. Edinger-Westphal nucleus: cells that project to spinal cord contain corticotropin-releasing factor. Neurosci Lett 83:13-19.

Coste SC, Kesterson RA, Heldwein KA, Stevens SL, Heard AD, StenzelPoore MP. 2000. Abnormal adaptations to stress and impaired cardiovascular function in mice lacking corticotropin-releasing hormone receptor-2. Nat Genet 24:403-409.

Dautzenberg FM, Hauger RL. 2002. The CRF peptide family and their receptors: yet more partners discovered. Trends Pharmacol Sci 23:7177.

De Fanti BA, Martinez JA. 2002. Central urocortin activation of sympathetic-regulated energy metabolism in Wistar rats. Brain Res 930:37-41.

De Souza EB. 1995. Corticotropin-releasing factor receptors: physiology, pharmacology, biochemistry and role in central nervous system and immune disorders. Psychoneuroendocrinology 20:789-819.

Fisher LA. 1989. Corticotropin-releasing factor: endocrine and autonomic integration of responses to stress. Trends Pharmacol Sci 10:189-193.

Gaszner B, Csernus V, Kozicz T. 2004. Urocortinergic neurons respond in a differentiated manner to various acute stressors in the EdingerWestphal nucleus in the rat. J Comp Neurol 480:170-179.

Grant G, Koerber HR. 2004. Spinal cord cytoarchitecture. In: Paxinos G, editor. The rat nervous system. San Diego: Elsevier Academic Press. $p$ 121.

Groenink L, Dirks A, Verdouw PM, Schipholt M, Veening JG, van der GJ, Olivier B. 2002. HPA axis dysregulation in mice overexpressing corticotropin releasing hormone. Biol Psychiatry 51:875-881.

Imaki T, Katsumata H, Konishi SI, Kasagi Y, Minami S. 2003. Corticotropin-releasing factor type- 1 receptor mRNA is not induced in mouse hypothalamus by either stress or osmotic stimulation. J Neuroendocrinol 15:916-924.

Keegan CE, Herman JP, Karolyi IJ, O'Shea KS, Camper SA, Seasholtz AF 1994. Differential expression of corticotropin-releasing hormone in developing mouse embryos and adult brain. Endocrinology 134:25472555.

Kimura Y, Takahashi K, Totsune K, Muramatsu Y, Kaneko C, Darnel AD, Suzuki T, Ebina M, Nukiwa T, Sasano H. 2002. Expression of urocortin and corticotropin-releasing factor receptor subtypes in the human heart. J Clin Endocrinol Metab 87:340-346.

Koob GF, Heinrichs SC. 1999. A role for corticotropin releasing factor and urocortin in behvioural responses to stressors. Brain Res 848:141-152.

Korosi A, Schotanus S, Olivier B, Roubos EW, Kozicz T. 2005. Chronic ether stress-induced response of urocortin 1 neurons in the EdingerWestphal nucleus in the mouse. Brain Res 1046:172-179.

Korosi A, Veening JG, Kozicz T, Henckens M, Dederen J, Groenink L, van der GJ, Olivier B, Roubos EW. 2006. Distribution and expression of CRF receptor 1 and 2 mRNAs in the CRF over-expressing mouse brain. Brain Res 1072:46-54.

Kozicz T, Korosi A, Korsman C, Tilburg-Ouwens D, Groenink L, Veening J, van der GJ, Roubos E, Olivier B. 2004. Urocortin expression in the Edinger-Westphal nucleus is down-regulated in transgenic mice overexpressing neuronal corticotropin-releasing factor. Neuroscience 123: $589-594$.

Lariviere WR, Melzack R. 2000. The role of corticotropin-releasing factor in pain and analgesia. Pain 84:1-12.

Latchman DS. 2002. Urocortin. Int J Biochem Cell Biol 34:907-910.

Lewis K, Li C, Perrin MH, Blount A, Kunitake K, Donaldson C, Vaughan J, Reyes TM, Gulyas J, Fischer W, Bilezikjian L, Rivier J, Sawchenko PE, Vale WW. 2001. Identification of urocortin III, an additional member of the corticotropin-releasing factor (CRF) family with high affinity for the CRF2 receptor. Proc Natl Acad Sci U S A 98:7570-7575.

Li X, Clark JD. 2001. Heme oxygenase inhibitors reduce formalin-induced Fos expression in mouse spinal cord tissue. Neuroscience 105:949-956.

Lovenberg TW, Liaw CW, Grigoriadis DE, Clevenger W, Chalmers DT, De Souza EB, Oltersdorf T. 1995. Cloning and characterization of a functionally distinct corticotropin-releasing factor receptor subtype from rat brain. Proc Natl Acad Sci U S A 92:836-840.

Maillot C, Wang L, Million M, Tache Y. 2003. Intraperitoneal corticotropinreleasing factor and urocortin induce Fos expression in brain and spinal autonomic nuclei and long lasting stimulation of colonic motility in rats. Brain Res 974:70-81.

Martinez V, Wang L, Million M, Rivier J, Tache Y. 2004. Urocortins and the regulation of gastrointestinal motor function and visceral pain. Peptides 25:1733-1744.

Merchenthaler I, Hynes MA, Vigh S, Shally AV, Petrusz P. 1983. Immu- 
nocytochemical localization of corticotropin releasing factor (CRF) in the rat spinal cord. Brain Res 275:373-377.

Millan MJ. 2002. Descending control of pain. Prog Neurobiol 66:355-474.

Million M, Wang L, Wang Y, Adelson DW, Yuan PQ, Maillot C, Coutinho SV, McRoberts JA, Bayati A, Mattsson H, Wu VS, Wei JY, Rivier J, Vale W, Mayer EA, Tache Y. 2005. CRF2 receptor activation prevents colorectal distension-induced visceral pain and spinal ERK1/2 phosphorylation in rats. Gut 55:172-181.

Molander C, Grant G. 1995. Spinal cord cytoarchitecture. In: Paxinos G, editor. The nervous system. San Diego: Academic Press.

Mulders WH, Meek J, Schmidt ED, Hafmans TG, Cools AR. 1995. The hypothalamic paraventricular nucleus in two types of Wistar rats with different stress responses. II. Differential Fos-expression. Brain Res 689:61-70.

Nijsen M, Ongenae N, Meulemans A, Coulie B. 2005. Divergent role for $\mathrm{CRF} 1$ and CRF2 receptors in the modulation of visceral pain. Neurogastroenterol Motil 17:423-432.

Okamoto S, Ishikawa I, Kimura K, Saito M. 1998. Potent suppressive effects of urocortin on splenic lymphocyte activity in rats. Neuroreport 9:4035-4039.

Oki Y, Sasano H. 2004. Localization and physiological roles of urocortin. Peptides 25:1745-1749.

Owens MJ, Nemeroff CB. 1991. Physiology and pharmacology of corticotropin-releasing factor. Pharmacol Rev 43:425-473.

Parkes DG, Weisinger RS, May CN. 2001. Cardiovascular actions of CRH and urocortin: an update. Peptides 22:821-827.

Perrin MH, Donaldson CJ, Chen R, Lewis KA, Vale WW. 1993. Cloning and functional expression of a rat brain corticotropin releasing factor (CRF) receptor. Endocrinology 133:3058-3061.

Potter E, Sutton S, Donaldson C, Chen R, Perrin M, Lewis K, Sawchenko PE, Vale W. 1994. Distribution of corticotropin-releasing factor receptor mRNA expression in the rat brain and pituitary. Proc Natl Acad Sci U S A 91:8777-8781.

Puder BA, Papka RE. 2001. Distribution and origin of corticotropinreleasing factor-immunoreactive axons in the female rat lumbosacral spinal cord. J Neurosci Res 66:1217-1225.

Reul JM, Holsboer F. 2002. Corticotropin-releasing factor receptors 1 and 2 in anxiety and depression. Curr Opin Pharmacol 2:23-33.

Rexed B. 1952. The cytoarchitectonic organization of the spinal cord in the cat. J Comp Neurol 96:414-495.

Reyes TM, Lewis K, Perrin MH, Kunitake KS, Vaughan J, Arias CA Hogenesch JB, Gulyas J, Rivier J, Vale WW, Sawchenko PE. 2001. Urocortin II: a member of the corticotropin-releasing factor (CRF) neuropeptide family that is selectively bound by type $2 \mathrm{CRF}$ receptors. Proc Natl Acad Sci U S A 98:2843-2848.

Schipper J, Steinbusch HW, Vermes I, Tilders FJ. 1983. Mapping of CRFimmunoreactive nerve fibers in the medulla oblongata and spinal cord of the rat. Brain Res 267:145-150.

Sehringer B, Schafer WR, Wetzka B, Deppert WR, Brunner-Spahr R, Benedek E, Zahradnik HP. 2000. Formation of proinflammatory cyto- kines in human term myometrium is stimulated by lipopolysaccharide but not by corticotropin-releasing hormone. J Clin Endocrinol Metab 85:4859-4865.

Sidman RL, Angevine JB, Pierce ET. 1971. Atlas of the mouse brain and spinal cord. Cambridge, MA: Harvard University Press.

Skelton KH, Owens MJ, Nemeroff CB. 2000. The neurobiology of urocortin. Regul Pept 93:85-92.

Skofitsch G, Insel TR, Jacobowitz DM. 1985. Binding sites for corticotropin releasing factor in sensory areas of the rat hindbrain and spinal cord. Brain Res Bull 15:519-522.

Smith GW, Aubry JM, Dellu F, Contarino A, Bilezikjian LM, Gold LH Chen R, Marchuk Y, Hauser C, Bentley CA, Sawchenko PE, Koob GF, Vale W, Lee KF. 1998. Corticotropin releasing factor receptor 1-deficient mice display decreased anxiety, impaired stress response, and aberrant neuroendocrine development. Neuron 20:1093-1102.

Song ZH, Takemori AE. 1990. Involvement of spinal kappa opioid receptors in the antinociception produced by intrathecally administered corticotropin-releasing factor in mice. J Pharmacol Exp Ther 254:363368.

Song ZH, Takemori AE. 1991. Antagonism of morphine antinociception by intrathecally administered corticotropin-releasing factor in mice. J Pharmacol Exp Ther 256:909-912.

Swanson LW, Sawchenko PE, Rivier J, Vale W. 1983. Organization of ovine corticotropin-releasing factor immunoreactive cells and fibers in the rat brain: an immunohistochemical study. Neuroendocrinology 36:165186.

Turnbull AV, Rivier C. 1997. Corticotropin-releasing factor (CRF) and endocrine responses to stress: CRF receptors, binding protein, and related peptides. Proc Soc Exp Biol Med 215:1-10.

Turnbull AV, Vaughan J, Rivier JE, Vale WW, Rivier C. 1999. Urocortin is not a significant regulator of intermittent electrofootshock-induced adrenocorticotropin secretion in the intact male rat. Endocrinology 140 $71-78$

Vale W, Spiess J, Rivier C, Rivier J. 1981. Characterization of a 41-residue ovine hypothalamic peptide that stimulates secretion of corticotropin and beta-endorphin. Science 213:1394-1397.

Van Pett K, Viau V, Bittencourt JC, Chan RK, Li HY, Arias C, Prins GS Perrin M, Vale W, Sawchenko PE. 2000. Distribution of mRNAs encoding $\mathrm{CRF}$ receptors in brain and pituitary of rat and mouse. J Comp Neurol 428:191-212.

Vaughan J, Donaldson C, Bittencourt J, Perrin MH, Lewis K, Sutton S, Chan R, Turnbull AV, Lovejoy D, Rivier C. 1995. Urocortin, a mammalian neuropeptide related to fish urotensin I and to corticotropin releasing factor. Nature 378:287-292.

Wang CC, Willis WD, Westlund KN. 1999. Ascending projections from the area around the spinal cord central canal: a Phaseolus vulgaris leucoagglutinin study in rats. J Comp Neurol 415:341-367.

Weitemier AZ, Tsivkovskaia NO, Ryabinin AE. 2005. Urocortin 1 distribution in mouse brain is strain-dependent. Neuroscience 132:729-740. 